\title{
A CRITIQUE OF THE'PSYCHIATRIC APPROACH TO CRIME AND CORRECTION
}

\author{
Michael HaKeem*
}

I

The Influence of Psychiatrists

The opinion of psychiatrists can have substantial or decisive influence in the determination of whether an offender is fit to stand trial, whether he is responsible for a crime, and whether he is to be executed or given a life sentence. It can play an important part in the decision whether to place him on probation or to send him to a correctional institution. It can, in many instances, affect the duration of the offender's penal servitude, the choice of the particular institution to which he is sent, his subsequent transfer to other institutions, and his activities within the institution. It can sway the estimate of his suitability for parole or pardon.

In jurisdictions having special sex offender laws, the psychiatrist's opinion is usually determinative of whether such an offender is to be dealt with under the customary procedures or under the provisions of these laws. In the latter event, he is released only on the psychiatrist's recommendation, and he can be confined for life. Some psychiatrists have insisted that such procedures should be extended to all offenders. They propose that the law should enable the lifelong incarceration or supervision of any offender, on the recommendation of a psychiatrist, even if his crime were only a minor one. As long ago as r928, a committee of the American Psychiatric Association, under the chairmanship of Dr. Karl A. Menninger, recommended the "permanent legal detention of the incurably inadequate, incompetent, and anti-social offenders irrespective of the particular offense committed. ..." Not one of the terms used in this grim scheme was defined. It was not even explained how an "antisocial" offender differs from one who is not antisocial. Not a scintilla of evidence was presented that psychiatrists, or anyone else, could distinguish between incurable and curable offenders. Another suggestion on this order has been voiced more recently by a psychiatrist and a law professor in the following statement, which should occasion alarm in any schoolboy who has fully appreciated the implications of his lessons in eighth-grade civics: "... [I]f analysis of the convict's personality indicates that he cannot safely be released, he may have to spend the rest of his life under legal supervision of some kind, even though the only crime he has actually committed was a minor one."2

* B.S. 1942, M.A. 1945, Ph.D. 1950, Ohio State University. Associate Professor of Sociology and Social Work, University of Wisconsin. Sociologist, Illinois State Prison, 1942-46. Contributor to sociological and correctional publications.

${ }^{1}$ Menninger, Medicolegal Proposals of the American Psychiatric Association, I9 J. Cam, L. \& Criminology 367, 376 (1928).

${ }^{2}$ Manfred S. Guttaiacher \& Henry Weihofen, Psychiatry and the Law $444-45$ (1952). 
The juvenile delinquent is also much at the mercy of psychiatrists. Adjudication as a delinquent, commitment to and release from various institutions, separation from home and family, placement in a foster home, the granting of probation, and a host of other decisions can depend largely on what a psychiatrist advises.

Psychiatrists have been engaged for a long time in a relentless and extensive campaign to extend the scope and power of their influence in the administration of justice, in the disposition of offenders, and in the policies and practices of correctional institutions and agencies. This campaign has now reached reckless and irresponsible proportions, and there has been resort to questionable tactics. Unseemly as it may appear, the profession of psychiatry has even gone so far as to bestow prizes, honors, and unabashed flattery upon judges who have handed down decisions that it views as favorable to its cause. And, in the service of this campaign, psychiatrists have produced a prodigious literature, much of which is propagandistic in nature. It is characterized by incautious and immodest effusions, misrepresentation, extraordinary contradictions, flagrant illogicalities, grossly-exaggerated claims, biased selection of data, serious errors of fact and interpretation, ignorance of the distinction between scientific questions and value judgments, lack of sophistication in research methodology, tautological trivialities presented in the guise of technical profundities, and language, subject matter, and procedures not bearing the slightest resemblance to anything medical. ${ }^{3}$

Some psychiatrists have insisted that they are still greatly hampered in their forensic work by certain traditional concepts, procedures, and laws governing the prosecution and disposition of offenders, and they have furiously assailed these restraining formalities. They hold that many of the basic tenets of American jurisprudence, which are designed to protect the rights of offenders, and many of the limitations on administrative discretion in the handling of offenders are "stupid" and should yield to make way for psychiatric knowledge. They argue that the law frustrates their desire to deal with offenders in ways they deem best. Menninger puts the general idea as follows: "The scientific attitude as shown in psychiatry must sooner or later totally displace existing legal methods." And he hurls this further challenge: ". . . [M] ust the lawyers still continue solemnly to apply mediaeval

\footnotetext{
'A number of psychiatrists have leveled all these criticisms, and others besides, against their colleagues. Wertham, to cite only one, has reviewed some of the literature on forensic psychiatry, and he finds it dangerous, erroneous, misleading, deceptive, highhanded, uninformed, unreliable, confused, unscientific, tautological, biased, and grossly defective in other ways. See the following for references to some of Wertham's reviews in which these criticisms are found: Wertham, Psychoauthoritarianism and the Law, 22 U. CHI. L. Rev. $336 \mathrm{n}$. I (1955). For the most brilliant and scholarly appraisal of the literature on forensic psychiatry and of the issues in the question of criminal responsibility, see Jerome Hald, Generai. Principles of Criminal Law c. $\mathrm{X}_{4}$ (1947); Psychiatry and Criminal Responsibility, 65 Yale L. J. $76 \mathrm{I}$ (1956).

- Karl A. Menninger, The Human Mind 448-49 (3d ed. 1945). Since making this statement, Menninger apparently has had some second thoughts. He now confesses that it is "an open professional secret" that psychiatrists do not know how to treat offenders. He also concedes that they cannot predict the possible dangerousness of such offenders. And he points out that psychiatrists are not even available for such work or for even doing research on the problem. See Menninger, Book Review, 38 Iowa L. REv. 697, 701-02 (1953).
} 
stupidities in the name of 'established precedent,' 'public policy,' and other mouthy archaisms?"5 It is these trends, developments, and pressures that recently prompted a lawyer to suggest: "... [I]f the criminal were in any position to elect between the psychiatrist and the jurist as the future guardian of his liberties, he may be well advised ... to re-elect the jurist."

During the past several years, psychiatrists have been emboldened to increasing arrogance because some judges and lawyers have finally shown greater disposition to yield to their blandishments and entreaties. No less a person than Supreme Court Justice William O. Douglas recently gave psychiatrists warm encouragement in their efforts to shape the administration of justice. Speaking at the graduation exercises of the William Alanson White Institute of Psychiatry, Psychoanalysis, and Psychology, he reassured them that "recent developments in the law should hearten psychiatrists that their pleas do not always fall on deaf ears." Justice Douglas presented no evidence whatsoever that he had assayed psychiatric knowledge to determine whether its scientific creditability merited such a friendly gesture. In fact, practically all his psychiatric citations were drawn from the propagandistic literature referred to above.

The most important step taken in recent years bearing on the relationship between psychiatry and the law is, of course, the decision in the Durham case, handed down in 1954 by the United States Court of Appeals for the District of Columbia. ${ }^{8}$ This decision was written by Judge David L. Bazelon and concurred in by Judges Henry W. Edgerton and George $T$. Washington. It overthrew the existing test of criminal responsibility and adopted a new and broader test similar in type to that for which psychiatrists have long been agitating. There can be no doubt that the basic motivation of this decision was to "recognize" psychiatry. This is precisely what Fortas, who was the court-appointed attorney representing Durham before the Court of Appeals and who advocated the adoption of the new test, sees as its chief significance. ${ }^{9}$ Very revealing, from the point of view of the motivations operating in some of the champions of psychiatry, is this further observation by Fortas, still referring to the Durham decision: "Its importance is that it is a charter, a bill of rights, for psychiatry. ..."10 An examination of the Durham decision itself leaves no doubt that it was designed to overcome psychiatric objections to the prevailing legal views on criminal responsibility.

Anyone familiar with the psychiatric journals and the literature on forensic psychiatry does not need to have documented the wild elation with which the Durham decision was acclaimed. Judge Bazelon himself could not have been idolized more had he discovered the cause and cure of schizophrenia, which, inci-

${ }^{5}$ Kari A. Menninger, The Human Mind 449 (3d ed. 1945).

- De Grazia, The Distinction of Being Mad, 22 U. CHI. L. Rev. 339, 352 (1955).

7 William O. Douglas, Law and Psychiatry 6 (1956).

${ }^{8}$ Durham v. United States, 214 F.2d 862 (D.C. Cir: i954).

' Fortas, Implications of Dutham's Case; t1 3 AM. J. Psychatry 577, 581 (1957).

${ }^{10}$ Id. at 579 . 
dentally, is conceded to be the most serious mental disease and one about which, some psychiatrists are frank to admit, knowledge is practically nil. ${ }^{11}$ Fulsome praise was certainly heaped upon Judge Bazelon. Forensic psychiatrists said that they were astonished and captivated by the depth and breadth of his medical knowledge and his comprehensive familiarity with medical and psychiatric literature. The following statement, made by a leading forensic psychiatrist, typifies the commentaries of this sort: "To this author, who has had very limited experience in reading legal opinions, it is indeed encouraging to find in this opinion such a wide study of the technical medical literature and such a thorough understanding of it."12

Now, an actual examination, item by item, of the citations in the Durham decision will show the complete absence of any reference to "technical medical literature" and will show that practically all the psychiatric citations are to the propagandistic literature whose defects have been already noted. Most of this literature contains nothing medical and practically nothing psychiatric. It contains mainly pleas and proposals, based in no small measure on the value judgments of psychiatrists, for changes in the laws, in criminal trial procedures, and in correctional policies. The Durham decision is not based on a competent and objective appraisal of the truth of psychiatric claims and of the pretensions of psychiatry to scientific knowledge. As a matter of fact, it is a highly-biased decision, in as much as it completely disregards the large number of researches and extensive theoretical discussions that have yielded adverse appraisals of psychiatry. But no matter, for the jubilation of psychiatrists was so lasting and unsubduable that more than three years after the Durham decision, the American Psychiatric Association officially honored Judge Bazelon. He was presented a "Certificate of Commendation" for what he had done for psychiatry, though it was not put quite that way, of course..$^{13}$

An excellent example of how important and even momentous decisions are sometimes made on the basis of crass naiveté is provided by the deliberations of the American Law Institute on the question of criminal responsibility in connection with its preparation of a Model Penal Code. One would have supposed that before formulating its recommendations regarding the complex and crucial question of psychiatric testimony and the procedures for handling the plea of insanity, the American Law Institute would have tried to come to an independent assessment of the nature, methodological soundness, theoretical coherence, logicality, predictive efficacy, objectivity, reliability, and validity of psychiatric research, contentions, and premises. One would have supposed that, at the very least, the Institute would have wanted to look into the question of the reliability and validity of psychiatric judgments. The course actually followed by the Institute, however, could not have deviated more from this procedure. It sought the advice of three psychiatrists. Two of these have been in the forefront of the assault on the criminal law and have been

${ }^{11}$ Hoch, The Etiology and Epidemiology of Schizophrenia, 47 AM. J. PUB. HEALTH 107r, 1074 (1957): Heath, Psychiatry, in 5 Ann. Rev. Med. 230 (I954).

${ }^{12}$ Guttmacher, The Psychiatrist as an Expert Witness, 22 U. CHr. L. Rev. 325, 330 (1955).

${ }^{18}$ ludge Bazelon Honored, II 4 AM. J. Psychintry 565 (1957). 
leaders in the campaign to promote forensic psychiatry. The American Law Institute depended for its recommendations mainly on a brief memorandum prepared by one of these advisers. ${ }^{14}$ This memorandum is misleading, grossly exaggerates the scientific status of psychiatric knowledge, does not present the available contradictory or nonconfirmatory data on various points asserted in it, and fails to make reference to even one of those psychiatrists who have denied that their profession has knowledge that would be of much help in the administration of justice. ${ }^{15}$ In addition to this memorandum, there was a "chummy" exchange of correspondence between the psychiatrist who prepared the memorandum and the Chief Reporter of the Institute's Model Penal Code project, by means of which the latter sought to learn about psychiatry and to secure clarification on various issues, particularly, one gets the distinct impression, to determine just what it is the psychiatrists want from lawyers. ${ }^{10}$

In view of the increasing importance of psychiatry in the fields of criminology, law, and corrections, the recent tendency of the law to embrace psychiatry to a greater extent than ever before, the unfortunate practice of some judges and lawyers to embark on this new course without thinking it necessary to inform themselves about psychiatry, and the fact that the glibness of some psychiatrists is in danger of being exceeded by the gullibility of some members of the legal profession, it becomes particularly imperative to scrutinize psychiatric knowledge and contentions. The present paper will review only a limited portion of these-namely, the psychiatric view of delinquency and crime as disease, the reliability of psychiatric diagnosis, and the two mental diseases most often discussed in connection wth delinquent and criminal behavior.

\section{II}

\section{Delinguency and Crime as Disease}

A journal bearing the redoubtable title, Postgraduate Medicine, published in one of its volumes such formidable reports as "Atresia of the Esophagus With or Without Tracheo-Esophageal Fistula" and "Herniated Cervical Intervertebral Disk Simulating Angina Pectoris." Among these and other equally weighty disquisitions, in the same volume, appeared an article with this starkly simple title: "Medical Responsibility for Juvenile Delinquency." 17 This was by a psychiatrist. It contained the usual rebuke of the law for not implementing psychiatric preachments about delinquency, along with an admonition to all who deal with this problem to accept medical concepts regarding it. In the meantime, the medical journals have been carrying an increasing number of articles on delinquency and crime.

\footnotetext{
14 Guttmacher, Principal Difficulties with the Present Criteria of Responsibility and Possible Alternatives, Model Penaz Code app. B (Tent. Draft No. 4, I955).

${ }^{25}$ To cite only the latest of these, Szasz says: "T . . . want to suggest, at the very least, that the current popular belief that psychiatry has much to contribute to jurisprudence may be ill-founded and misleading." Szasz, Psychiatric Expert Testimony-Its , Covert Meaning and Social Futnction, 20 PsYchiatRY 3I3, 3I4 (1957).

${ }^{10}$ Model Penal Code app. C (Tent. Draft No. 4, 1955).

${ }^{17}$ Blackman, Medical Responsibility for Juvenile Delinquency, 10 PostGrad. MED. 499 (1951).
} 
In the series of articles on crime that appeared in Life several months ago, there was displayed a dramatic photograph of a criminal whose brain waves were being examined by doctors in a clinic. The caption explained that this was done to determine whether the offender needed "surgery" or "psychiatry."18

Recently the New York Temporary State Commission on Youth and Delinquency issued a report summarizing a large number of hearings it had held throughout the state to get a public airing of views on all aspects of delinquency. Hundreds of people were heard. The report concluded that the psychiatric orientation emerged as the most popular approach to the understanding, prevention, and treatment of delinquency. ${ }^{19}$

In the course of a symposium on crime, Edwin J. Lukas, who is a lawyer and former executive of a crime prevention agency, stated that if the matter were looked at from the proper perspective, "the parallel between crime and physical illness becomes almost exact."20

These are all merely incidents exemplifying the operation and impact of an orientation vigorously promoted by psychiatrists: Delinquency and crime are medical problems. Some put the proposition in so many words, simply and tersely, as when one psychiatrist claims that "juvenile delinquency is a medical problem. . ."21 Some state it more elaborately: ". . [ [T] he whole problem of criminality or criminology is in the field of human behavior psychopathology, the understanding of which requires medical and psychiatric training." 22 Sometimes it is phrased colorfully: "The modern surgical operating amphitheater developed out of dirty public barber-shops. The physicians took surgery away from the barbers a century ago; now they are taking criminology away from jailers and politicians."23 Sometimes it takes the form of an even more explicit battle cry: "Criminology today, like demonology of yesterday, is a battlefield for the rightful possession of which the psychiatrist is still fighting." ${ }^{24}$

Certain premises underlie the view that delinquency and crime are medical problems. These premises are, of course, that these phenomena constitute disease and that offenders are "sick people." This notion, too, is put in a rich variety of

${ }^{18}$ Life, Oct. 7, 1957, p. 160. Neither the caption nor the story related the experiment in which ten EEG records were submitted to five well-known electroencephalographers for independent interpretation. On only four out of the ten was there agreement on the presence or absence of pathology; on only three out of the ten was there agreement on localization of the pathology; and on only one out of the ten was there agreement on the two factors combined. See Blum, $A$ Note on the Reliability of Electroencephalographic Judgments, 4 NeuroLoGr 143 (1954). No psychiatrist protested this omission, despite the fact that the American Psychiatric Association has been much concerned with securing accurate reporting of news about psychiatry to the public.

${ }^{10}$ N.Y. Temporary State Comm'n on Youth and Delinquency, Youth and Delinguency 78 (1956).

${ }^{20}$ Lukas, A Criminologist Looks at Criminal Guilt, in Edmond N. CAHN (ED.), CRIMINAL GuILt 145 (Social Meaning of Legal Concepts No. 2, 1950).

${ }^{21}$ Eugene Davidoff \& Elinor S. Noetzel, The Child Guidance Approach to Juvenile DeINNQUENCY 150 (195I).

${ }^{22}$ Seliger, Criminal Hygiene, Fed. Prob., Jan.-March 1946, pp. I6, 19.

${ }^{23}$ Kare A. Menninger, The Human Mind 45i (3d ed. r945).

st Gregory Zilboorg \& George W. Henry, A History of Medical Psychology 4r9 (ig4r). 
ways. One psychiatrist calls delinquents "seriously sick children."25 Another says that knowledge of psychopathology is the "only means of preventing crime."20 Often delinquency is listed along with "neurosis, psychosis, and psychosomatic illness" to underscore the idea that it is just another mental illness to be encompassed within the same frame of reference as any other. ${ }^{27}$ Another example of this practice is provided by a committee of the House of Representatives. After a "health inquiry" at which psychiatrists testified, the committee issued a report wherein mental illness subsumes delinquency. ${ }^{28}$ Sometimes, the point is set forth calmly, as in Glueck's sedate but unconvincing argument that some of the knotty legal issues in criminal responsibility would be eased if crime were viewed as a sickness and not as a moral transgression. ${ }^{29}$ More often, it is proclaimed ardently, as in the following statement by Karpman, promulging the policy of a journal established and edited by him: "The Archives will fight vigorously for the recognition of criminal psychiatry. It will fight for the recognition of the criminal as a very sick person, much sicker than either psychosis [sic] or neurosis [sic]. . ."30

But greatest effectiveness in drumming the ideology that delinquency and crime are disease and offenders are sick is probably not achieved when it is explicitly propounded, whether vociferously or quietly. More persuasive is its exposition unaccompanied by any theoretical elaboration in defense of it, as though there could be no question in the world about the truth of the matter. And resort to the ubiquitous medical analogy clinches this subtle form of presentation. To illustrate, one psychiatrist says: ${ }^{31}$

Using medical terms delinquency can be described as a very widespread illness, affecting mainly young people and causing gross symptoms [in certain proportions of this population]. . . . [M]ild cases usually are treated at home. . . . The illness, on the whole, is benign. Unfortunately [after recovery, in certain proportions of cases] it is followed by relapses. The illness then takes a prolonged course but even then in most cases heals off.

Another says that "theft, like rheumatic fever, is a disease of childhood and" adolescence, and, as in rheumatic fever, attacks in later life are frequently in the nature of recurrences." 32 A third puts it as follows: "When a patient goes to the hospital with a physical illness, he receives medication and therapy directed spe-

${ }^{25}$ Eveoleen N. Rexford, in Dougzas A. Thod Clinic for Children, Inc., ANn. Rep. I7 (1956).

${ }^{26}$ Ruth S. Eisssler, Scapegoats of Society, in K. R. Eisster (ED.), Senrchligirs on Delineuzncy 304 (1949).

${ }^{27}$ George J. Mohr \& Marian A. Despres, The Stormy Decade: Adolescence 210 (I958).

${ }^{28}$ House Committee on Interstate and Foreign Commerce, Health Inquiry, H.R. Rep. No. $1338,83 d^{\prime}$ Cong., 2d Sess. 123 (1954).

${ }^{28}$ Glueck, Changing Concepts in Forensic Psychiatry, 45 J. CRIM. L., C. \& P.S. 123, 127 (1954).

${ }^{30}$ Karpman, Criminal Psychodynamics: Al Platform, Arch. Crins. Psychodrn. 3, 96 (r955).

${ }^{32}$ Balint, On Punishing Offenders, in George B. Wilbur \& Warner Muensterberger (Eds.), Psychoanalysis aNd Culture 254, 266 (1951).

${ }^{32}$ Bowlby, Forty-Four Juvenile Thieves: Their Characters and Home-Life, 25 INT'2 J. Psrcto-ANAL. I9 (I944). 
cifically to his ailment. ... We send our children to correctional institutions to be treated for an illness. ..."."33

So powerful is the conviction of some psychiatrists that crime stems from mental disease that they have held the commission of crime in itself constitutes conclusive evidence of the presence of mental disease. Again, this aspect of the ideology usually draws on the medical analogy. The thesis runs as follows: Just as fever is a symptom of physical disease, so crime is a symptom of mental disease. The following excerpt provides an example of just such a formulation: “... [J] ust as symptoms of physical illness are danger signals that call for remedial measures, a criminal act, in a high percentage of cases, is a signal of psychological distress and a natural appeal for remedy." $\mathrm{A} 4$ like conclusion has been reached by many psychiatrists, another one of whom writes: "It is becoming increasingly apparent that chronic incorrigible criminal behavior is symptomatic of mental disease. . ."35 About thirty years ago, Menninger hopefully prophesied that "the time will come when stealing or murder will be thought of as a symptom, indicating the presence of a disease, a personality disease, if you will. ..."36 Twenty-five years later, another psychiatrist expressed the identical sentiment: "One may hope that a day will come when the very fact of having committed a crime will be regarded as evidence of a mental disease. . . ."37 As early as I930, the American Medical Association, acting on the recommendations of representatives of medicine, psychiatry, and law, officially went on record in support of the view that a diagnosis of mental disease is permissible "even when the criminal has shown no evidence of mental disease other than his criminal behavior."

In the meantime, some psychiatrists have shown disdain for the legal presumption of sanity, which one dismisses, redundantly, as that "hoary old legal dogma."30 It has been proposed by more than one psychiatrist that the law should presume not sanity, but insanity. One of these has commented that the legal doctrine of the "reasonable man" does not square with the findings of modern psychiatry. He intimates that the law should replace the presumption of sanity with the presumption of insanity, so confident is he that the offender is more likely to be insane than sane. ${ }^{40}$

However it is put, the irrepressible and irresponsible campaign-for that is what it is-to implant the view that crime and delinquency are disease and offenders are sick people has had great impact. The public, as well as important officials, is more and more coming to actually believe the physicians who tell it that the criminal is a

${ }^{33}$ Tarrasch, Delinquency Is Normal Behavior, 29 Focus 97, I0I (1950).

32 Ralph S. Banay, We Calz Them Criminals 6 (1957).

${ }^{a 5}$ Louis Linn, A Handbook of Hospital Psychiatry 331 (1955).

${ }^{30}$ Menninger, Medicolegal Proposals of the American Psychiatric Association, I9 J. CRIm. L. \& CrumINOLOGY 367,373 (1928).

${ }^{37}$ Benjamin Karpana, The Sexual Offender and His Offenses 218 (1954).

${ }^{38}$ Psychiatry in Relation to Crime, 95 A.M.A.J. 346 (1930).

${ }^{80}$ Overholser, The Place of Psychiatry in the Criminal Law, I6 B.U.L. REv. 322, 329 (1936).

${ }^{10}$ Poindexter, Mental Illness in a State Penitentiary, 45 J. Crim. L., C. \& P.S. 599, 562 (1055). 
sick person in need of medical treatment. Fortas, who has already been cited, thinks that the Durham decision and other decisions which show a greater acceptance of psychiatric doctrines by the courts indicate that the judges involved "suspect that mental disorders may figure in criminal activities with vastly more frequency than is currently recognized by our legal procedures. . .."41 If Fortas is correct, then these judges are showing remarkable resoluteness, even if their conclusion is nothing but a surmise. All the more so because they have presented no scientific evidence to substantiate even a "suspicion," and particularly so in view of the tact that, though these judges may have at least tentatively made up their minds on the matter, psychiatrists are in a state of complete disaccord about it.

For, though it is true that the psychiatric propagandists have gained widespread support for their ideology and have succeeded in getting judges, lawyers, correctional administrators, and others to implement it, the psychiatric profession does not present a united front on this issue. As is true in regard to practically every fundamental postulate in psychiatry, so in regard to this problem, there is vast disagreement, confusion, and contradiction. This can be documented by a few citations, remembering that these constitute an insignificant proportion of those that could be assembled.

One psychiatrist thinks that all offenders show traits differentiating them from nonoffenders, ${ }^{42}$ but another says that the great majority do not vary much from the average person." Another psychiatrist advises that "no one would maintain that all criminals are mentally ill or abnormal,"44 thereby showing unfamiliarity with the writings of Karpman and scores of others who maintain exactly that. ${ }^{45}$ Menninger gives the assurance that psychiatrists "do not consider that many offenders in our prisons are mentally sick . ..," of psychiatrists who have contended just the opposite. ${ }^{47}$ Schilder maintains that "the majority of criminals are normal . .."; 48 however, Abrahamsen counters that "the 'normal' offender is a myth. ..."49 East has concluded that the "mentally abnormal criminal is the exception and not the rule . ..," ", a view challenged by another psychiatrist who claims that "one does not expect anti-social conduct from normally constituted individuals. . .."51 Neustatter decries what he calls the "fallacy" of

41 Fortas, supra note 9, at 577-78.

15 Henderson, Psychopathic Constitution and Criminal Behaviour, in L. Radzinowicz \& J. W. C. Turner (Eds.), Mental Agnormaltty and Crime 106 (English Studies in Criminal Science No. 2, 1944).

${ }^{3}$ Schmideberg, The Analytic Treatment of Major Criminals: Therapeutic Results and Technical Problems, in Ersst.ER, op. cit. supra note 26, at 174 .

4t David Stafford-Clark, Psychatry To-Day 221 (1952).

${ }^{48}$ Benjamin Karpana, The Sexual Offender and His Offences 562 (1954).

46 William C. Menninger, Psychiatry: Its Evolutton and Present Status 123 (1948).

${ }^{17}$ Haugen, Coen, \& Dickel, Possibilities of Psychotherapy in Prisoners, 3I Focus 83 (1952).

${ }^{18}$ Paul Schilder (arr. by Lauretta Bender), Psychonnalysis, Man, and Society 238 (195I).

${ }^{40}$ David Abrahamsen, Who Are the Guilty? 125 (1952).

${ }^{50}$ Norwood EAst, Soctety ANd the Criminal 228 (1951).

62 Peskin, The Modern Approach to Legal Responsibility, the Psychopath and the M'Naghten Rulles, I FORENSTC MED. I89; I9I (1954). 
regarding all criminality as psychological illness, ${ }^{52}$ but many psychiatrists share the opinion that "every criminal has a defective personality. ...." R33 Regarding juvenile delinquents, one psychiatrist is satisfied that "the largest percentage" of serious delinquents is normal, ${ }^{54}$ but this is offset by another who is satisfied that all juveniles who are in repeated trouble are "mentally ill." E5 English and Pearson, the wellknown child psychiatrists, write that the psychiatrist "does not believe that all delinquents are sick people ...,", psychiatrist, who insists that she does not understand what is meant by "normal delinquency." R7 Regarding murder, Glueck finds that no murderer is normal when he commits his crime, ${ }^{58}$ only to be contradicted by another practitioner who finds that there are normal murderers. ${ }^{59}$

One would have supposed that this muddle in itself would have been sufficient to make of psychiatry a profession so utterly humble as practically never to be heard from. At the very least, one would have supposed that psychiatrists would have been too chagrined to prescribe a course of action for society to follow in tackling its crime problem. Quite to the contrary, however, psychiatrists and those convinced by them have moved apace to put their views into effect on many fronts. Changes in the laws and certain court decisions have already been mentioned. All over the country, medically-oriented clinics, diagnostic centers, and residential treatment facilities are being established for delinquents and "emotionally disturbed children." ${ }^{\text {"0 }}$ An administrator of the New York Department of Mental Hygiene has reported that large numbers of delinquent children are now being certified directly to institutions for the mentally ill in his state. He said that "the line between criminality and mental illness or mental defect is being redrawn." ${ }^{\text {"61 }}$ The top administrator of the same department has commented that the psychiatrists have been "singularly successful with the courts," and, increasingly, offenders are being sent to "civil state hospitals instead of hospitals for the criminally insane."

A well-known psychiatrist has revealed that in New York City, Puerto Rican

to Ncustatter, Psychiatry and Crime, izo Practitroner 39 I (1953).

${ }^{23}$ Banay, Crime and Aftermath: Results of a Research on the Individual Offender, in NaT'z ProBation aNd PAROLE Ass'N, I948 Yearbook 35 (I949). (1955).

"Curran, Specialized Techniques in the Treatment of Juvenile Delinquency, 157 A.M.A.J. I08

${ }^{\mathrm{E}}$ Juvenile Delinquency (Boston, Mass.), Hearings before the Subcommittee to Investigate Juvenile Delinquency of the Senate Committee on the Tudiciary, 83d Cong., 2d Sess. 293 (1954).

oo O. Spurgeon English \& Gerald H. J. Pearson, Emotional Problems of Living 290 (rev. ed. 1955).

${ }^{57}$ Bender, cited by Karpman, Psychodynamics of Child Delinquency: Further Contributions, 25 AM. J. ORthopsychistRY 238, 274 (1955).

${ }^{B 8}$ Glueck, supra note 29, at 130-3x.

"royal Comm'n on Capital Punishment, Minutes of Evidence 359 (1949).

"The term "emotionally disturbed" is never operationally defined in the proposals to establish institutions to house children who are said to belong in that category.

${ }^{11}$ Hunt, Mental Hygiene and Correction: An Operational Blueprint, in Proceedings of the Frederick A. Moran Memorual Instituti on Delinguency and Crime 21 (1953).

${ }^{85}$ Hoch, The Changing Role of State Mental Hospitals, in 1956 Annuar Conference of the MiLbank Memorial Fund, Programs for Communtry Mental Heatif x49 (I957). 
adolescents who become "emotionally disturbed" because of their difficult circumstances have been incorrectly diagnosed as mentally ill and have been wrongly committed to mental hospitals. He has insisted that, despite the fact that "judicial notice has been taken of such falsely committed cases," there has been no improvement in the situation. ${ }^{63}$ Recently, a child guidance clinic made a special study of 500 cases referred to it. In only twenty-one per cent of these were the referrals regarded as unequivocally justified. ${ }^{\text {a }}$ An examination of the reported behavior and problems on account of which these children were referred for diagnosis of their mental condition will show that the overwhelming majority were trivialities, universally found in children, and designated "normal" by many psychiatrists, even when manifested in marked degree.

Recently, a psychiatrist issued a very strong warning and protest that there has been an enormous increase in the diagnosis of schizophrenia among children. She pointed out that schizophrenia "is not a disease of childhood." tions of delinquents engaged in the customary types of gang activities who were wrongly given diagnoses of the more malignant mental diseases. She commented: "A child who commits a crime is now likely to be diagnosed schizophrenic and sent to a mental hospital." She further pointed out that normal children were being committed to mental hospitals. Finally, she reported on a clinical re-evaluation of sixty children "in trouble for many different reasons" who were diagnosed as schizophrenic. It was found that the diagnosis was wrong in practically all cases. ${ }^{67}$

How can psychiatrists tell whether or not a delinquent or a criminal is mentally sick? Psychiatrists, like all other medical practitioners, presumably find this out by a process universally used in medicine-diagnosis. It would be sheer folly to disregard the clamorous insistence of psychiatrists that delinquency and crime are disease and that the offender is mentally sick, if for no reason other than the high authority from which it emanates. On the other hand, surely anyone would agree that it would be equal folly-it would be irresponsible-to encourage it, to advance it, to support it, to act on it, to incorporate it in court decisions and laws without a careful examination of the evidence. Therefore, the first step should be an appraisal of the scientific status of the process of diagnosis by which psychiatrists determine the mental condition of offenders.

\section{III}

\section{The Reliability of Psychiatric Diagnosis}

Generally, the specific technical diagnosis of an offender's mental condition is not in issue, as such, and does not concern the court or the correctional administrator. The court is interested in the consequences and implications of the defendant's

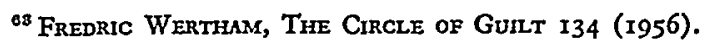

"4 Forrest N. Anderson \& Hezen C. Dean, Some Aspects of Child Guidance Clinic Intake Policy and PRACTTCES 9 (1956).

${ }^{\text {es }}$ Mosse, The Misuse of the Diagnosis Childhood Schizophrenia, 114 AM. J. PsychintRY 791 (1958).

${ }^{\circ 0}$ Ibid.

${ }^{\circ}$ Ibid. 
mental condition, in so far as the law gives special effect to these in the judgment and disposition to be made, regardless of the specific diagnostic category. And the correctional administrator is concerned with decisions that can be altered in accordance with the psychiatric counsel he gets regarding the attributes and results thought to be associated with the various types of mental disorders afficting his charges.

The psychiatrist himself, however, presumably thinks, as do all physicians, in terms of the specific diagnosis. Diagnosis is the process whereby the psychiatrist determines which one or more of the large variety of mental diseases and disorders a subject has. On the basis of the diagnosis, the psychiatrist comes to conclusions regarding the course, symptomatology, prognosis, malignancy, treatment, and other aspects of the subject's ailment that can help determine judicial and correctional decisions. All the decisions that can be affected by psychiatric judgment will ultimately rest on diagnosis, which is the basic instrumentality of medical practice.

A striking example of the importance of diagnosis and of how a specific diagnostic category can have crucial bearing on the disposition of offenders is provided by a recent occurrence. It has been reported that in a certain jurisdiction, the staff of a mental hospital that has been customarily testifying that psychopathic or sociopathic personality is not a mental disease formally announced that henceforth it would testify that this condition does constitute a mental disease. ${ }^{68}$ Other psychiatrists, in and outside of hospitals, in this and in other jurisdictions, do not share the view and would not testify that the condition in question is a mental disease. Thus, the fate-execution, or acquittal on the grounds of insanity-of a murderer, say, can depend in the final analysis on a specific diagnosis and on the value judgment of psychiatrists regarding that diagnosis.

Take, as another example, the question of the malignancy of the various mental diseases. The malignancy ascribed to an offender's mental disease can certainly have a bearing on decisions made about him. It can, in the case of a sex offender, for instance, figure in the determination as to when to release him, if ever. Again, it depends upon the philosophy of psychiatrists whether a mental disease is benign or malignant, and this philosophy differs markedly among different psychiatrists. Take the psychoneuroses, for example. One practitioner describes them as a "relatively benign group of personality disturbances . . .,"69 while another reports that "some authorities regard the psychoneuroses as the most serious disease threat of modern civilization."70

If so much can depend on psychiatric diagnosis, the question can be raised: How reliable is it? ${ }^{71}$ Surely the courts, the correctional administrators, and the welfare

${ }^{8 B}$ In re Rosenfeld, I57 F. Supp. 18 (D.D.C. I957).

${ }^{00}$ Arthur P. Noyes, Modern Clinical Psxchiatry 445 (4th ed. I953).

70 Enward A. Strecker, Fundaxentals of Psychiatry 38 (5th ed. 1952).

71 Many persons do not understand the meaning of the concept of reliability in scientific methodology. Reliability means agreement by the experts on their theories. observations, and conclusions-agreement not by fiat, but by scientific demonstration of the correctness of any particular proposition. To the extent that a discipline is scientifically established, a question regarding any particular aspect of its subject matter will yield essentially the same answer from all experts. If the same question brings forth widely divergent responses, then it should be clear that the point involved has not been scientifically established. 
officials must be assuming that psychiatric diagnoses have adequate reliability. It is inconceivable that they would embrace psychiatry unless they were convinced that the judgments, diagnoses, and conclusions of its practitioners are reliable.

The literature of.the forensic psychiatrists often sets forth implicit and explicit persuasions that psychiatric diagnoses are as reliable as those of any other branch of medicine. Zilboorg, for example, writes: "The clinical judgment of the psychiatristprovided he be properly qualified-must be accepted by the courts to the same extent as the clinical judgment of a surgeon or an internist." ${ }^{12}$ More than one psychiatrist has expressed resentment at the proclivity of some observers to raise questions about psychiatric diagnoses and judgments. One of these has called for what looks like unquestioning acceptance of these judgments: ${ }^{73}$

If society sees fit to appoint neutral experts to determine the sanity of the defendant, then society should demonstrate its faith in these experts and abide fully by their findings. This [apparently referring to noncompliance with psychiatric findings] is tantamount to calling in a physician for a serious medical illness and then not following his advice.

Assurance has been given that "psychiatry has its nosology just as do the other branches of medicine. Psychiatric clinical entities are as discrete as the cardiac or the pulmonary disorders."74 Statements like the following are often encountered: "Modern psychiatric diagnoses ... in acute and chronic mental disorders, are as accurate as those in tuberculosis, communicable disease, or other illness."75

Time and again, in the face of overwhelming evidence to the contrary, psychiatrists have dismissed as baseless the charge that they are frequently in disagreement about their diagnoses, observations, and theories. They insist that they are in agreement on most issues. Overholser makes a daring misrepresentation on this point, typical of many others that could be cited $:^{76}$

There is general agreement among psychiatrists upon the essential facts and the significance of words and actions, although there are minor differences in theory. The differences and disagreements are much exaggerated by the critics, and constitute one of the allleged reasons for the reluctance of the legal profession to accept any more readily than they do psychiatric concepts and teachings.

If one turns from these writings of the forensic psychiatrists to the writings of leading psychiatrists who have no special interest in forensic work; who address themselves to the problem of diagnosis as a scientific issue to be solved by research; who do not spend an inordinate amount of time haranguing and harassing the legal

${ }^{72}$ Zilboorg, A Step Toward Enlightened Justice, 22 U. CHr. L. Rev. 331, 335 (1955).

${ }^{73}$ Mental Disorder and Criminal Responsibility: A Sympositum, 3 J. Soc. ThERAPY 66, 87-88 (1957). In referring to "neutral experts," this psychiatrist apparently has in mind those jurisdictions and situations in which the expert does not appear as a partisan for the defense or for the prosecution.

${ }^{7}$ GutTMACHER \& Weirofen, op. cit. supra note 2, at 27 . Guttmacher has elsewhere taken a different position: "Psychiatric nosology is, at best, an unsatisfactory business. . . " See MANFred S. Gutrmaciren, SEX OPFENSES I02 (195I).

"5. A. E. Bennetr, Eugene Hargrove, \& Bernice Engle, The Practice of Psychiatry in Genemal Hospitals 91 (1956).

${ }^{70}$ Winfred Overholser, The Psychitrist and the LAw 23 (I953). 
profession; who are not busily engaged in fighting for changes in the laws which would bring them into greater conformity with their own value position; who do not seize upon every writing and speaking engagement as an opportunity to seduce judges and others about the present status of psychiatric knowledge; who do not pout that the court psychiatrist has as much right as the prosecutor and defense counsel to be heard as to the disposition of defendants; ${ }^{77}$ and who, in other ways, are not clamoring to enhance their power to control and decide the destiny of offenders, one gets an entirely different picture of the state of psychiatric diagnosis. As a matter of fact, one arrives at the unmistakable conclusion that psychiatric diagnosis is grossly unreliable, is beset by numerous unsolved complexities, and is, in fact, in a state of chaos.

Take, for example, the report of the I95I annual meeting of the American Psychopathological Association. ${ }^{78}$ This meeting was devoted to the topic of psychiatric diagnosis and was only incidentally concerned with forensic matters. By culling certain statements from the report of this meeting, it is possible to show that some psychiatrists' appraisals of the reliability of diagnosis and of the competence of psychiatric research is in striking contrast to the samples of exaggerated claims set forth above. Disregarding the specific authorship of the statements, it was submitted at this meeting that the concept of psychosis is not "definable"79 and is so fallacious as to have "facilitated loose and unscientific thinking" in psychiatry; ${ }^{80}$ that the term schizophrenia means many different things to different people; ${ }^{81}$ that "it is hardly necessary to stress the extent to which there is confusion in regard to the diagnosis at the present time"; 82 that because there is no agreement on psychodynamics among the different schools of thought at present, "we encounter a complete confusion" in diagnosis; ${ }^{83}$ that "the personality and biases of the psychiatrist may also influence his choice of a diagnostic label"; ${ }^{84}$ that because there is "looseness and ambiguity" in the terms used by psychiatrists, progress in diagnosis and treatment is retarded; ${ }^{85}$ that "the psychiatric literature is replete with dissensions and controversies" even on "elementary problems"; 86 that diagnosis in child psychiatry "has literally been a "Tower of Babel" "; that in the military situation, psychiatrists may deliberately make invalid diagnoses in order to comply with administrative exigencies rather than medical dictates; ${ }^{88}$ that the extent of agreement among psychiatrists on specific diagnoses was found through research to be "neither satisfactory nor desirable"; that an examination of researches reported in the issues of eleven psychiatric and related journals over a two-year period showed grave defects and serious lack of

${ }^{77}$ Guttmacher, Adult Court Psychiatric Clinics, in University of Colorado Conference on Crime, Crimes op Violence $5 \mathrm{~T}$ (1950).

${ }^{78}$ Paul H. Hoch \& Joseph Zubin (Eds.), Current Problems in Psychitric Diagnosis (1953).

${ }^{20}$ Id. at 25.

${ }^{81} \mathrm{Id}$. at $\mathrm{I} 80$.

${ }^{8 s}$ Id. at 50.

${ }^{85} I d$. at 267 .

${ }^{87}$ Id. at 220 .

${ }^{80} \mathrm{Id}$. at $3 \mathrm{I}$.

${ }^{82}$ Id. at $4 \mathrm{I}$.

"sid. at 108-09.

onld. at 60 .

${ }^{80} I d$. at $23 \mathrm{I}$.

${ }^{88} I d$. at 55 . 
sophistication in experimental methodology; ${ }^{20}$ that psychiatric research is hampered by "an almost total lack of training in terms of scientific disciplines."

It must not be supposed that such strictures are confined to this one report. Far from it; for, although one could never get a true picture of the situation by reading only the highly deceptive literature of the forensic psychiatrists, the unreliability of psychiatric diagnosis is a widely-documented fact. Ironically enough, on the very eve of the Durham decision, no less a source than the American Journal of Psychiatry editorially took to task those psychiatrists who were attacking the existing rules and laws of criminal responsibility and urging their abrogation. The editorial took the position that these psychiatrists had not presented convincing evidence that psychiatry had made the advances claimed by them and on the basis of which they were demanding changes in the laws. ${ }^{22}$ The editorial further reminded these doughty fighters that medical experts do not agree even "as to the diagnosis of textbook types of insanity." 93

Even more recently, a psychiatrist cautioned: "Diagnostic judgments are currently so invalid and unreliable that little weight should be attached to them." more recently still, Mosse, who has already been cited as expressing alarm at the increasing tendency for psychiatrists readily and wrongly to diagnose delinquents as schizophrenic, stated: "No valid classification of mental diseases in children has yet been-worked out. ..."95 Further, she explained: "One of the most important gaps in our knowledge is that the limits of normal for children of different ages have not yet been established,"96 a view shared by other cautious clinicians. It might be interesting to select the final example from a context as far removed as possible from any immediate forensic concern. A psychiatrist who has done research on the relationship between peptic ulcer and mental disorder has observed that one of the difficulties in such research is the "unreliability of psychiatric diagnosis." $\mathrm{He}$ also commented that even the same clinicians are inconsistent with themselves. ${ }^{07}$

Psychiatrists have sought to convince lawyers, correctional administrators, and others not only that their diagnoses are as reliable as those of other branches of medicine, but also that they, like other medical practitioners, have reliable and valid tools, devices, tests, and procedures to augment and confirm their clinical diagnoses and impressions. For example, one psychiatrist has said: "Just as the medical person uses $\mathrm{x}$-ray and laboratory tests in making a physical diagnosis, so are there similar routines to determine the personality structure." has maintained that psychiatrists have "certain physical and psychological tests and

${ }^{20} \mathrm{Id}$. at 20. $\quad{ }^{01} \mathrm{Id}$. at 20.

${ }^{90}$ Criminal Irresponsibility, 110 AM. J. Psychutri 627, 628 (1954).

${ }^{88}$ Ibid.

94 Thorne, Psychiatric Responsibilities in the Adminstration of Criminal lustice, 2 Arch. Crus. Psychodyn. 226, 236 (1957).

${ }^{95}$ Mosse, supra note 65 , at 791 .

${ }^{00} 1 d$. at 793 .

${ }^{97}$ Gosling, Peptic Ulcer and Mental Disorder-II, 2 J. Psychom. Res. 285 (1958).

${ }^{28}$ Marie Nyswander, The Drug addict as a Patient 58 (1956). 
well recognized constellations of symptoms, to help guide us in our judgments."99

As in regard to the contention about reliability, so in regard to this contention, these writers rarely spoil their positive declarations by referring to quite a different kind of observation that has been made by psychiatrists and other experts about their diagnostic instruments. A psychiatrist in the College of Physicians and Surgeons of Columbia University, for example, has considered the matter of diagnosis and diagnostic tools. He comes to a conclusion that is diametrically opposed to the ones cited. He holds that in contrast to the physical diseases, the existence of which can be determined on the basis of "a recognizable syndrome" and by the use of certain devices and tests, "in emotional and mental illnesses this is almost never the case; even in the so-called major mental and emotional illnesses, such guides to detection and diagnosis are almost entirely lacking." ${ }^{100}$ To cite another example, the New York State Commissioner of Mental Hygiene recently said: ${ }^{101}$

While other fields of medicine often can augment or even verify clinical diagnoses by other methods-by tests that are independent of the clinical appraisal of the patientthis is generally not true in psychiatry. Although I am fully aware of the claims that it can be done, I maintain that it cannot.

Most of the time, there is particular praise for the Rorschach test. One gets the impression that it is regarded by psychiatrists as the most powerful tool at their disposal and one which goes a long way in putting psychiatry on a par with any other medical specialty. Strecker, for example, appearing for the defense in a murder trial in which the life of the defendant was at stake, testified:102

I regard the Rorschach test as very scientific, well-tried, in common use in all good mental hospitals, relied on by the majority of psychiatrists I know, and in my opinion the interpretation has been in agreement with my own opinion and diagnosis in more than $95 \%$ of the cases.

Wertham has stated, "The Rorschach Test is a valid scientific method."103 Banay has extolled the Rorschach test. ${ }^{104}$ Guttmacher has claimed that the Rorschach test can be "amazingly revealing." say that "definite diagnostic criteria have been established" for it. They are astounded by "how much a skillful Rorschach technician can tell about a patient that he has never seen, merely from analyzing his test responses."106

${ }^{\circ}$ Guttmacher, Criminal Responsibility in Certain Homicide Cases Involving Family Members, in Paul H. Hoch \& Joseph Zubin (Eds.), Psychiatry and the Law 74 (1955).

${ }^{200}$ Ginsburg, The Neuroses, 286 Avinals 55 (1953).

${ }^{101}$ Hoch, The Etiology and Epidemiology of Schizophrenia, 47 AM. J. Pub. Hearth 1071 (I957).

${ }^{103}$ Richard Gehman, A Murder in Paradise 137 (rev. ed. 1956). Dr. Strecker did not reveal whether his own diagnoses were checked for reliability in any way other than by their agreement with the Rorschach test. If diagnoses yielded by the Rorschach test are unreliable and Dr. Strecker's diagnoses are in agreement with them, then Dr. Strecker's diagnoses have to be unreliable. As will be noted shortly, the Rorschach test has been found by some experts to be grossly unrcliable.

${ }^{103}$ Fredric Wertham, Seduction of the InNocent 56 (1954).

${ }^{104}$ Banay, Applications of Clinical Psychology to Crime and Delinquency, in I DANIEL Brower \&

Lawrence E. Abt (Eds.), Progress in Clinical Psychology 459, 463 (1952).

${ }^{200}$ Manfred S. GuttMacher, Sex Offenses 31 (195I).

${ }^{100}$ GutTMACHer \& Weirofen, op. cit. supta note 2, at 22. 
All these misleading effusions fail even to refer to another side of the story. The other side of the story is provided by the experimental researches, theoretical analyses, and methodological observations that have demonstrated the unreliability, invalidity, subjectivity, theoretical weaknesses, illogicalities, and questionable premises of the Rorschach test. It is these considerations that led a psychologist, who is an expert on the construction and validation of personality tests, to conclude that the results secured through the Rorschach test are not superior to the results that would be secured by writing the different diagnoses on the faces of a die and then casting the die to determine the personality of a subject. ${ }^{107}$ It is a review of some of these researches and judgments, which need not be repeated here, that also led the present writer to conclude elewhere: "... [T] he results of the Rorschach test should not be used as a basis for reaching decisions about people and they should not be allowed to enter in any serious way into deliberations looking toward the disposition of cases." ${ }^{108}$ Testimony regarding a defendant's personality and mental condition which is based in whole or in part on the Rorschach test should certainly not be allowed in court.

The gross unreliability of psychiatric diagnosis-which, in the courts, takes the form of the so-called battle of the experts-has been one of the most painfully embarrassing ordeals for forensic psychiatrists. Indeed, it is one of the leading concerns of the psychiatric profession as a whole that it is in connection with forensic work that the unreliability of diagnosis comes in for the greatest amount of public scrutiny, keeps psychiatry in disrepute with those who have sufficient scientific sophistication to understand its implications, and provides merriment for people. Psychiatrists have tried by every possible means to escape this morass. They have denied the importance of diagnosis. They have even disparaged diagnosis. They have said that a diagnosis is a triviality that cannot encompass the actual object of psychiatric study- "the whole man." But the study of the whole man is philosophy, not medicine. In any event, psychiatrists of this persuasion have been confronted by powerful and even angry reminders from colleagues that if they claim to be physicians, then they must diagnose. They are told that proper treatment depends on it, prognosis depends on it, scientific progress depends on it. The American Journal of Psychiatry has issued the following editorial warning on the matter: "... [I]n psychiatry, as well as in all medical disciplines, accurate diagnosis is the keystone of appropriate treatment and competent prognosis."109 A textbook has taken this firm stand: "The contemptuous attitude toward diagnosis, which is so prominent a feature of many contemporary schools [of psychiatry], runs counter to the entire spirit of medicine."110 One psychiatrist put it very bluntly: $:^{111}$

\footnotetext{
${ }^{107}$ H. J. Eysenck, SENSE aNd NoNsense in Psychology 221 (1957).

${ }^{108}$ Hakeem, A Critique of the Psychiatric Approach to the Prevention of Invenile Delinquency, 5 Soc. Proв. 194, 196-97 (1958).

${ }^{109}$ The New Nomenclature, 109 Am. J. Psychitatry 548 (1953).

${ }^{110}$ W. Mayer-Gross, Eliot Slater, \& Martin Roth, Clinical Psychiatri 6 (1954).

${ }^{211}$ Pasamanick, Patterns of Research in Mental Hygiene, 26 Psychitric Q. 577, 578 (1952).
} 
With really unpardonable ignorance, it.is stated by some psychiatrists that the diagnosis of a psychiatric entity is unimportant and that the so-called psychodynamics are the essential object of study. This would be partially excusable, only if they could give the dynamics in more than hypothetical formulation. Such statements display a lamentable lack of insight into the essentials of scientific procedure and do not speak happily for the future of research in the field.

Some psychiatrists have taken refuge from diagnosis by giving a description of personality instead. But Ackerman, as do others, objects to this and points out that what goes into such a description is "too largely determined by subjective emphases in a particular examiner's mind."112 This, of course, is only another way of saying that descriptions of personality can be as unreliable as diagnostic categorization.

In desperation, forensic psychiatrists have turned to the legal profession for help. They have proposed and vigorously advocated various legal changes the effect of which would be to conceal diagnostic unreliability or to make the diagnosis less accessible to attack. Probably the greatest favor that judges, lawyers, and legislators can do for the profession of psychiatry is to implement its plans to eliminate the "battle of the experts" and to render the psychiatrist's diagnosis unchallengeable. The relentless attempts of the psychiatrists to bring these changes about and the increasing tendency of the legal profession to yield to their entreaties need not be detailed here, since these issues are the subject of a forthcoming paper by the writer. For now, it need only be noted that psychiatrists have insisted that somehow, sometime, the lawyers must find ways to extricate the profession of psychiatry from a very embarrassing state of affairs.

It might be argued that the unreliability of psychiatric diagnoses and judgments is flagrantly evident in the psychiatric literature and cannot be concealed. But the availability of evidence has made no difference to those judges and lawyers who are making momentous decisions and recommendations hospitable to psychiatry.

Furthermore, some judges are not disturbed by the disagreements of physicians. One of these is Judge John Biggs, Jr. $\mathrm{He}$ is Chief Judge of the Third Judicial Circuit of the United States. Judge Biggs has been very friendly to psychiatry. His opinions reflect the kind of views whose adoption psychiatrists have been urging. These opinions have been widely cited and hailed by psychiatrists. The American Psychiatric Association bestowed the Isaac Ray Award upon Judge Biggs. This is given annually to a member either of the legal or of the psychiatric profession who has contributed notably to the improvement of the relations between psychiatry and the law. As part of the award, Judge Biggs received one thousand dollars. As another part, he had the privilege of giving a series of lectures on forensic psychiatry at a university of his choice. These lectures have been published in a book. ${ }^{113}$. An examination of the notes in this book reveals that it contains almost no citations

${ }^{113}$ Ackerman, Psychiatric Disorders in Children-Diagnosis and Etiology in Our Time, in Paur H. Hoch \& Joseph Zubin (Eds.), Current Problems in Pstchintric Diagnosis 22i (r953).

${ }^{118}$ John Biggs, JR., The Guilty Mind (1955). 
of psychiatric literature. In the rare instances when such citations do occur in the book, they refer to the propagandistic literature the nature of which has been discussed more than once in this paper. Judge Biggs has said, "Let me make it clear that I am not objecting to even skillful physicians differing in their diagnoses." $\mathrm{He}$ further commented, "Heaven knows they differ less than lawyers and judges,"114 thus overlooking the fundamental differences between medicine and law, the serious implications of the disagreements of physicians, the distinction between scientific questions and value judgments, the fact that the social judgments of psychiatrists are being mistaken by themselves and others for medical judgments, and the methodological and philosophical reasons why it is perfectly legitimate for judges and lawyers to disagree but not permissible for psychiatrists to do so.

It has been seen that psychiatric diagnoses are grossly unreliable. But psychiatrists do diagnose. In the courts, to repeat a point, life or death can depend upon their diagnoses. It is important, therefore, to look into the nature of those diseases and other mental infirmities which psychiatrists diagnose in offenders. Obviously, it will not be possible to discuss all such diseases. Therefore, the two most important ones have been selected for consideration: psychopathic personality and psychoneurosis.

IV

\section{Psychopathic Personality}

Probably the mental condition most often discussed in connection with delinquency and crime is "psychopathic personality" or "psychopathy."115 One investigator has listed 202 terms used as equivalents of these, ${ }^{110}$ but even this list does not exhaust the number. In 1952, the American Psychiatric Association adopted the new term, "sociopathic personality," for this condition.17 Since then, the old term continues to be the more widely-used one. The old term and its derivative forms will be used here for convenience.

${ }^{214}$ Biggs, The Lawyer Looks at the Doctor, 28 DeL. STATE MED. J. 122, 125 (1956).

${ }^{115}$ The words "psychopathic" and "psychopathy" used in the present context should not be confused with one of their dictionary definitions-namely, a generic term meaning mental disorder. "Psychopathic personality" or "psychopathy" is used by psychiatrists to designate a type of mental disease.

Recently, Dr. Albert H. Arenowitz, a juvenile court psychiatrist, speaking before the Ross Club of the University of Wisconsin, misinformed a large audience that the concept of psychopathic personality was no longer used, having been discarded by psychiatrists many years ago. In the few months before and after this disavowal of the concept, a large number of books and many dozens of articles devoted in whole or in part to psychopathic personality were published. The concept has been and is now one of the most important in psychiatry and the most important in forensic psychiatry. Under its newer name, "socio. pathic personality," this is the diagnosis a psychiatrist applied to Charles Starkweather in the course of his widely-publicized trial in Lincoln, Nebraska, in May 1958, for one of the eleven murders he admittedly committed.

${ }^{126}$ Cason, The Psychopath and the Psychopathic, 4 J. Crim. Psychopatr. 522 (1943).

${ }^{1 x 7}$ The change in terminology has not resulted in any other changes in the concept. Discussions on "sociopathic personality" are identical to discussions on "psychopathic personality." Often, authors using the new term explicitly state that they mean by sociopathic personality what was meant by the old term psychopathic personality. 
Without exception, on every point regarding psychopathic personality, psychiatrists present varying or contradictory views. There is danger that such a statement will be mistaken for hyperbolic emphasis. Therefore, it should be explicitly made clear that the statement is meant to be taken literally. Not all points can be illustrated here, but a few will be presented, remembering that whenever one authority is cited, dozens of others taking a like position on the point in question could be cited.

Psychiatrists are in disagreement on whether they are in agreement or in disagreement on the subject. One investigator questioned seventy-five authorities, sixty-four of whom were psychiatrists, on how much agreement exists among psychiatrists on the concept of sexual psychopathy. Forty-two replied that there is no substantial agreement and twenty-four that there is. ${ }^{118}$ Campbell is surprised at "how much conformity exists in the minds of practicing psychiatrists concerning psychopathic personality"; ${ }^{119}$ Wilson and Pescor, on the other hand, say that "practically every psychiatrist has his own idea of what constitutes a psychopathic personality. ..."120 Cleckley, intending to show that great unanimity exists regarding this concept, says: "If a psychiatrist, in speaking to another about a patient, uses the term psychopath, there is seldom any misunderstanding as to the sort of patient in question"; ${ }^{121}$ but Duval states: ". . . [A]ctually I am not sure whether we know what we are talking about when we speak of the psychopath. ..."122 Thompson attributes the great amount of agreement among psychiatrists on the concept of psychopathy to the fact that it "is such a well-defined entity that its symptoms and characteristics are as well known to the psychiatrist as the symptoms of measles are known to the pediatrician"; ${ }^{123}$ but this is countered by Kennard's observation: "Clinicians do not even agree, actually, as to whether such a category exists."124 Overholser and Richmond express the view that "there is no general agreement among psychiatrists as to what type of personality should be designated psychopathic,"125 only to be contradicted by Guttmacher and Weihofen, who say that while opinion about psychopathy is not unanimous, "there is considerable agreement."126 Lowrey, referring to the diagnosis of psychopathic personality, thinks that "the important point is that psychiatrists agree there is such a group of abnormal personalities . ..", ;2t while Stevenson, writing about the same concept, puts the issue

${ }^{118}$ PaUl W. Tappan, The Habitual Sex Offender 57 (I950).

${ }^{110}$ John D. Campaell, Everyday Psychitry 67 (2d ed. 1949).

${ }_{120}$ J. G. Wilson \& M. J. Pescor, Problems in Prison Psychiatry 134 (1939).

${ }^{121}$ Cleckley, The Psychopath Viewed Practically, in Robert M. Lindner \& RoBert V. Seliger (Eds.), Handiook of Correctional Psychology 395 (1947).

122 Daniel Blain (Ed.), Steps Forward in Mental Hospitals i78 (1953).

128 George N. Thompson, The Psychopatric Delinguent and Crimnal 39 (1953).

${ }^{196}$ Kennard, in discussion of Hill, EEG in Episodic, Psychotic and Psychopathic Behaviour: A Classification of Data, 4 Electroenceph. \& Cinn. Neurophys. 419, 440 (1952).

193 Winfred Overholser \& Winifred V. Richmond, Handbook of Psychatry 184 (1947).

198 GUTTMACHER \& WeIHOFEN, op. cit. supra note 2, at 88.

${ }^{127}$ LAwson G. LoWrey, Psychiatry for SoctaL Workers 260 (2d ed. I950). 
as follows: "There is much disagreement as to the validity of this category as a diagnosis."128

Is psychopathic personality a clinical entity? There are contradictory views on this question, varying from those who, after extensive study of the matter, hold that it is "a very definite clinical entity"128 to those who, after extensive study of the matter, hold that "there is no such entity."130 Is psychopathic personality a serious condition? Every conceivable shade of opinion is espoused. Wertham is satisfied, as are other clinicians, that psychopathy is a "mild kind of abnormality not gross enough to be called a mental disease"131 or to be regarded as a "psychosis."182 But Thorne is satisfied that it is just as malignant as a psychosis; ${ }^{133}$ Carroll explicitly states that it is a "mental disease"; ${ }^{134}$ and Darling and Sanddal say it is a "psychosis." 135

How frequently is psychopathic personality found among offenders? It depends entirely on which psychiatrist is asked, because estimates of the proportion of criminals who are psychopaths and the proportion of psychopaths who are criminals vary from o to Ioo per cent. One psychiatrist holds that the criminal is "rarely" psychopathic. ${ }^{136}$ Another claims that criminals are "usually" psychopathic. ${ }^{137}$ Two others insist that all psychopathic personalities are pathological criminals. ${ }^{138}$ Another counters that many psychopaths are not criminals. ${ }^{139}$ One goes so far as to reveal that he has seen "as many psychopathic judges, lawyers, police officers, and psychiatrists as psychopathic criminals." ${ }^{\text {A40 }}$ A reception center of a state prison system has reported that only 2.3 per cent of prisoners admitted in a twelve-year period were diagnosed as psychopaths by psychiatrists. ${ }^{141}$ Three psychiatrists speculate that about five per cent of convicted prisoners may be psychopathic. ${ }^{142}$ Two others found fourteen per cent of prisoners psychopathic. ${ }^{143}$ Another holds that one-fourth to onehalf of all criminals are psychopathic. ${ }^{144}$ Three others are convinced that three-

${ }^{228}$ George S. Stevenson, Mental Health Planning for Soctal Action 144 (1956).

${ }^{129}$ Hervey Clecklex, The Mask of Sanity 210 (3d ed. 1955).

${ }^{130}$ Abrahamsen, Study of 102 Sex Offenders at Sing Sing, Fed. Prob., Sept. 1950, pp. 26, 27.

${ }^{131}$ Frepric Werthas, The Show of V1OLence 85 (I949).

${ }^{132}$ Id. at 128.

${ }^{233}$ Thorne, supra note 94, at 235.

${ }^{234}$ Royal. Comm'n on Capital Punishment, op. cit. supta note 59, at 551.

${ }^{236}$ Darling \& Sanddal, A Psychopathologic Concept of Psychopathic Personality, 13 J. CLiN. \& Exper. PsYchopath. I75, I78 (1952).

${ }^{236}$ Hulbert, Constitutional Psychopathic Inferiority in Relation to Delinquency, 30 J. Crim, L. * Cruminoloci 3, II (1939).

${ }^{287}$ C. S. Bluemel, The Troubled Mind $49 x$ (1938).

${ }^{138}$ J. M. Niflsen \& George N. Thompson, The Engrammes of Psychistry 190 (1947).

${ }^{230}$ LOWREY, op. cit. supra note 127 , at 267.

${ }^{210}$ Abraham Myerson, Speaking of Man 185 (1950).

${ }^{141}$ Pennington, Psychopathic and Criminal Behavior, in L. A. Pennington \& Irwin A. Bero (Eds.), Introduction to Clinicar Psychology 424 (2d ed. 1954).

${ }^{142}$ Stafford-Clark, Pond, \& Doust, The Psychopath in Prison: A Preliminary Report of a Co-Operative Research, 2 BRIT. J. DeLINe. II7, I27 (I95I).

${ }^{24 a}$ Wilson \& PESCOR, op. cit. supra note 120, at 134 .

16 Kari. A. Menninger; The Human Mind, 158 (3d ed. 1945). 
fourths of prisoners under twenty-one years of age are psychopaths. ${ }^{145}$ Another testifies that ninety per cent or more of incarcerated delinquents are potential, if not actual, psychopaths. ${ }^{146}$

What types of crimes do psychopaths commit? No one answer can be given, seeing that different psychiatrists take entirely different positions. One has said that psychopaths "are driven ... to deeds of violence which are as uncontrollable as a tidal wave."147 Two others, not even mentioning violence, have stated that the antisocial behavior of psychopaths "consists of every form of petty misdemeanor."148 Another has explained that a "common feature" of the psychopath is the commission of serious crimes of violence. ${ }^{149}$ This is contradicted by the opinion of another, who has concluded that the crimes of psychopaths "generally ... are not in the category of major crimes."150 Two psychiatrists have asserted that "crimes of violence such as assault, rape and murder . . . are typical acts of psychopathic criminals,"151 but this is opposed by the view of another, who has said that the typical psychopath is not likely to commit "major" crimes. ${ }^{152}$ One psychiatrist, medically describing the psychopath as an "incorrigible monster," time comforting, observation: "We can thank heaven that the type is rare because the offenses within the range of the genuine psychopath are without limits." "They will," says he, without giving a shred of evidence, "commit profit murder for a sum as low as twenty-five dollars." 154 There is more reassurance in the observation of another psychiatrist, who, while he presents no evidence either, holds that the crimes of the psychopath are "usually ... relatively minor."155 In a widely-used textbook, three psychiatrists, who are apparently disinclined to get embroiled in these dizzying controversies, have taken refuge in the following sweeping position about the psychopath's behavior: "The behavior of these patients may vary from amiable lying to criminal activity." 156

What causes psychopathic personality? No single answer would do justice to the large array of factors implicated by different psychiatrists in the causation of this malady. There is no disease like psychopathy in the whole realm of medicine. It is the only disease known for which some practitioners blame conditions in the home and some, conditions in the central nervous system. Birnbaum finds that

${ }^{145}$ Haugen, Coen, \& Dickel, stlpra note 47 , at 85 .

${ }^{146}$ Royal Comm'n on the Laws Relating to Mental Ileness and Mental Deficiency, Minutes OF EvideNCE 943 (I954).

${ }^{147}$ Royal Comm's on Capital. Punishment, op. cit. stipra note 59, at 462.

${ }^{118}$ Louis J. Karnosh \& Edward M. Zucker, A Handbook of Psychuatry 206 (1945).

${ }^{140}$ Royal Comm's on Capital. Punishment, op. cit. supra note 59, at $49 \mathrm{r}$.

150 Edward A. Strecker, Basic Psychiatry 299 (1952).

162 Nielson \& Thompson, op. cit. supra note 138 , at 191 .

${ }^{163}$ Hervey Cleckley, The Mask of Sanity 37 (3d ed. 1955).

${ }^{263}$ David Abrahansen, Who ARe the Guilty? 212 (1952).

106 Id. at $16 \mathrm{I}$.

${ }^{160}$ Tarumianz, Nesy State Facilities for Criminally Inclined Psychopaths in Delaware, 22 Dex. State MED. J. 163, 165 (1950).

${ }^{100}$ Jack R. Ewalt, Edward A. Strecker, \& Franklin G. Ebaugh, Practical Clinical Pstchiatry 258 (8th ed. I957). 
psychopathy is "constitutional; that is innate and (probably) hereditary"; ${ }^{157}$ Bender, that it is the purest example of "psychogenic or environmentally determined behavior disorders ..."; ${ }^{158}$ Lichtenstein and Small, that in many cases, it is directly attributable to endocrine dysfunction; $;^{159}$ Greenacre, that it is due to poor parent-child relations; ${ }^{100}$ Nielsen and Thompson, that cerebral trauma is the commonest cause; ${ }^{101}$ O'Conner, that deprivation of "blood-sugar" has been implicated; ${ }^{102}$ and Palmer, that "deprivation of Mother Love" is the basic factor. ${ }^{103}$ Two distinguished experts on psychopathy caution that different factors can cause this disease in different patients. They hold that in some cases, the predominating cause will be such factors as poverty, a broken home, and so on; and in other cases, "disturbance of the prefrontal hypothalamic connections," brain injury, and the like. ${ }^{104}$ Finally, with refreshing simplicity, one psychiatrist suggests, in effect, that psychopathic personality results from the failure to train the child to behave himself. ${ }^{105}$

What do psychiatrists say about treatment of psychopaths? Everything, for viewpoints on the treatment of this disease vary markedly from psychiatrist to psychiatrist. Asked by the Royal Commission on Capital Punishment whether any progress had been made toward curing psychopaths, one expert answered, "I am afraid not."166 A different psychiatrist, answering the same question submitted by the same Commission, said that the curability of the psychopath is "surprisingly large."167 When it comes to specific treatments that have been proposed or tried, there is rampant diversity. They run the gamut from attempts to incorporate the subject into groups having athletic, cultural, political, or religious interests, ${ }^{108}$ to brain surgery. ${ }^{169}$ One intriguing type of treatment has been reported in which "the psychopathic delinquent is brought before an awesome panel of doctors who literally say nothing beyond an initial expression of their desire to help the culprit once he is honestly interested in helping himself." The hazards of this approach are tremendous, judging from one observation that has been made: "... [T] [Te psychopath can sit out the doctors easily enough." 170

Psychiatrists do not disagree only with each other. Some disagree with themselves. Often it is possible to find one and the same psychiatrist taking contradictory

${ }^{107}$ Birnbaum, A Court Psychiatrist's View of lutvenile Delinquents, 261 Annats 55, 59 (1949).

${ }^{268}$ LaURetta Bender, Aggression, Hostility and ANxiety in Children 152 (1953).

${ }^{100}$ P. M. Lichtenstein \& S. M. Smali, A Handbook of Psychiatry 88 (1943).

${ }^{100}$ Greenacre, Problems of Patient-Therapist Relationship in the Treatment of Psychopaths, in Lindnen \& Seliger, op. cit. supra note 121 , at 379.

$10 x$ NIELSEN \& THOMPSON, op. cit. supra note $\mathrm{x}_{3} 8$, at 169 .

${ }^{102}$ William A. O'Connor, Psychiatry 304 (1948).

${ }^{108}$ Harold Palmer, Psychopathic Personalities i2 (1957).

104 David Henderson \& R. D. Gillespie (with Ivor R. C. Batchelor), a Text-Book of Psychiatry 388 (8th ed. 1956).

${ }^{105}$ Wooley, A Dynamic Approach to Psychopathic Personality, 35 So. MEd. J. 926 (1942).

${ }^{168}$ Royal CoMm's on Capital Punishment, op. cit. supra note 59, at 307 .

${ }^{107}$ Id. at 501 .

${ }^{208}$ Oskar Diethelas, Treatment in Psychiatry 426 (2d ed. 1950).

${ }^{100}$ Darling \& Sanddal, supra note 135 , at 179.

${ }^{170}$ Ruth L. Munroe, Schools of Psychonnalytic Thought 293 (1955). 
stands on the same question from publication to publication, on different pages of the same publication, and on the same page of the same publication. For example, Banay, a psychiatric consultant to the Federal Bureau of Prisons, has taken curious positions on the psychopath. In a conference on criminal responsibility held in early I957, he rejected the concept of psychopathic personality, saying: "I am very much in disagreement with the diagnosis of psychopath. Psychopath means we don't know what is wrong with him."171 Just about the time Banay was making this statement, a book written by him was published. In this book, he describes in detail a treatment for psychopaths: ${ }^{.72}$

Marked success in the treatment of some psychopaths has been obtained through a combination of electrocoma and psychotherapy. The treatment requires hospitalization for eight months to a year and it consists of a series of electrocoma treatments followed by analytically oriented psychotherapy. This is followed by further ambulatory treatment under therapeutic conditions. The procedure has been tested sufficiently to show that many aggressive psychopaths can be guided to adequate social adjustment, over-all change of temperamental trends and freedom from criminal inclinations.

Banay is prescribing drastic and lengthy "therapy" for a diagnostic category he rejects.

Guttmacher took the position in I95I that "the diagnosis of a psychopathic personality is practically meaningless." He elaborated on the point by urging that the term be discarded or restricted to a type of case described by Cleckley. ${ }^{173}$ But in the I951 annual report of the court clinic of which Guttmacher is Chief Medical Officer, it is recorded that forty-eight cases were diagnosed as psychopaths of a type other than that described by Cleckley. ${ }^{174}$ Furthermore, in his memorandum to the American Law Institute, Guttmacher raises no question whatever about the validity of the diagnosis of psychopathic personality, and, in fact, he favors the institutionalization of psychopaths for an indeterminate period. ${ }^{175}$ Guttmacher's clinic is attaching to offenders a diagnosis which he admits is practically meaningless. And, in one place, he is recommending possible lifelong custody for offenders who are diagnosed as having a disease which, in another place, he says is practically meaningless.

McCarthy and Corrin state that the psychopath "is within normal limits intellectually ...."; however, on another page of the same book, they state that "the psychopath is inferior ... intellectually. ..." Again, these authors hold that the condition of the psychopath is "clear-cut and uniform in its symptomatology ..."; but in the very next paragraph, on the same page, still referring to the same diag-

${ }^{171}$ Mental Disorder and Criminal Responsibility: A Symposium, supra note 73, at 82.

${ }^{179}$ Ratph S. Banay, We Catz. Thems Criminals i7o (1957).

${ }^{178}$ Guttmacher, Diagnosis and Etiology of Psychopathic Personalities as Perceived in Our Time, in Paul H. Hoch \& Joseph Zubin (Eds.), Current Problems in Psychiatric Diagnosis i55 (r953).

${ }^{174}$ Medical Officer of the Suprease Bench of Baltimore City, Report 8 (195I).

${ }^{175}$ Guttmacher, Principal Difficulties with the Present Criteria of Responsibility and Possible Alternatives, Model Penal Code app. B, at 777 (Tent. Draft No. 4, 1955). 
nosis, they assert that "there is no symptom, syndrome or behavior dynamics upon which one may base a diagnosis."

How is psychopathic personality diagnosed? Numerous psychiatrists have explicitly and implicitly admitted that to diagnose this disease they do not need to examine the subject's body - which, incidentally, is universally acknowledged to be the only legitimate object of investigation in every other branch of medicine. To diagnose psychopathic personality, the psychiatrist needs to examine only the subject's FBI record. Numerous psychiatrists have explicitly stated that they can make this diagnosis if they have access to only the social history of the "patient," particularly a record of his crimes. One example is Strecker's statement that "since there are no strong and clear-cut diagnostic criteria, the diagnosis [psychopathic personality] has to be made retrospectively on the basis of a long history of psychopathic behavior."177 An even more pointed example is provided by the following quotation: "For diagnosis of these states [psychopathic personality] an adequate social history is imperative. The psychopath is not apt to reveal his difficulties with the environment voluntarily." subject in the category of psychopathic personality, "the antisocial behavior of the patient should be the principal manifestation of the disorder."179 Another textbook advises that "no diagnosis of psychopathic personality should be made in the absence of punishable or censurable acts episodically carried out."180 Davidson, although discussing psychopathy in witnesses rather than in offenders, makes the following statement, which obviously would apply in any context: ${ }^{181}$

The diagnosis of psychopathy is not made by examination but by a review of the life history. Examination shows nothing. The life history shows a record of trouble, of shiftlessness, of nomadism, of dishonesty, of nonconformity, of mischief or of some similar trait. When this is the history in a witness of good intelligence and obvious sanity, one has the right to suspect psychopathy.

It is clear what is being admitted in all these excerpts: To be able to diagnose psychopathy, the psychiatrist needs to have evidence that the subject shows a history of psychopathy. A history of psychopathy consists of the subject's record of crime or of other social maladjustment. Given this history, the psychiatrist can diagnose psychopathy. Obviously, a psychiatrist is not needed to diagnose psychopathy. The policeman or the file clerk keeping criminal records could fully measure up to the task.

It should be very clear by now-to all except those who are immovably determined not to allow reason to interfere with their worshipful admiration of psychiatry

${ }^{170}$ Daniel J. McCarthy \& Kenneth M. Corrin, Medical Treatment of Mental Diseases 402, 403, 405 (1955).

177 Edward A. Strecker, Fundamentals of Psychiatry i82 (5th ed. 1952).

${ }^{178}$ Dunn, The Psychopath in the Armed Forces: Review of the Literature and Comments, 4 Psychiatry 25I, 253 (I94I).

${ }^{270}$ Ewalt, Strecker, \& Ebaugh, op. cit. stipra note 156 , at 258.

${ }^{180}$ O'Convor, op. cit. stipra note 162 , at 300 .

${ }_{181}$ Davidson, How Trustworthy Is the Witness?, 2 J. Forensic MEd. 14, 88 (I955). 
(an all too common foible)-that there is no such thing as a medical (psychiatric) "disease" called psychopathic or sociopathic personality. This disease, like so many others in psychiatry, is a figment of the fertile imagination of psychiatrists. Psychopathy is nothing but a synonym for crime and delinquency. Whether or not a person is said to have this disease depends, like so many other diseases in psychiatry, more on what is going on in the head of the psychiatrist than what is going on in the head of the "patient." Just such an observation comes from an unexpected source. Karpman has noted: ${ }^{182}$

... [I]t is perhaps more likely that in studying roo consecutive cases diagnosed psychopathic personality, what we get is not an understanding of the patient, but a study of the mind of a psychiatrist, that is what he means when he makes a diagnosis of psychopathic personality. It is then discovered that the average psychiatrist calls an individual psychopathic if in some way the individual has gone against the social grain.

Despite all the evidence available, only an insignificant proportion of which has been presented here, despite the disconcerting observation by a psychiatrist that "at present there is no objective proof that they [psychopaths] are ill rather than wicked ..." ; ${ }^{183}$ despite the fact that Cleckley, one of the foremost proponents of the concept of psychopathy, grants that its "psychopathology ... is debatable and scarcely to be proved in courts," 184 despite the angry accusation by Kinberg, the internationally known forensic psychiatrist, that in their approach to psychopathic personality, psychiatrists are practicing something that looks very much more like quackery than medicine, ${ }^{185}$ the courts are admitting testimony about this diagnosis and are allowing the adjudication and disposition of cases to be influenced by it. This concept and psychiatric testimony about it should not be allowed in court, no disposition of cases should be based on it, and it should not be considered in any serious way in deliberations about defendants. No laws incorporating this concept, in any of its forms or under any of its names, should be passed. Legislation of this type already passed should be repealed. And, it goes without saying, correctional decisions should not be based on such a diagnosis.

In the meantime, society, especially the legal profession, would be wise to keep a very close watch over those courts that allow psychiatrists to testify about this concept. A court that would allow this is just as likely to allow testimony on witchcraft. More heed should be given to those psychiatrists who are capable of at least some sensible judgment about this matter, as illustrated in the following reflection: "Perhaps our psychopathic personality is the heretic or witch in modern guise."186

${ }^{182}$ Karpman, Psychopathy as a Form of Sacial Parasitism-A Comparative Biological Study, ro J. Clin. Psychopath. 160, I72 (1949).

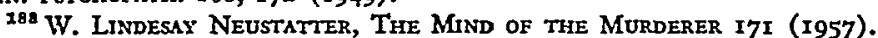

184 Cleckley, The Psychopath Viewed Practically, in Robert M. Lindner \& Rosert V. Seliger (Eds.), Handbook of CoRrectional Psychology $4 \mathrm{II}$ (1947).

${ }^{105}$ Kinberg, On the Concept of "Psychopathy" and the Treatment of So-called "Psychopaths," 93 J. Mental Scr. 93 (1947).

${ }^{180}$ Roche, Truth Telling, Psychiatric Expert Testimony and the Impeachment of Witnesses, 22. PA. B.aR Ass's Q. 140, 152 (1951). 
And no special perspicacity is needed to see a statement like the following, made by a psychiatrist in the course of an assault on the law for its reluctance to show greater hospitality to psychiatry, for the fraudulent pretense that it is: "... [J]udges have ridden roughshod over perfectly valid scientific discoveries such as the nature of psychopathy. ...."187

\section{$\mathrm{V}$}

\section{Psychoneurosis}

Another mental condition frequently said to be associated with delinquent and criminal behavior is psychoneurosis, or, to use the equivalent and shorter term, neurosis. It is impossible to state briefly the psychiatric position on the relationship between neurosis and delinquency or crime for two reasons: first, there is endless disagreement among psychiatrists on every facet of the concept of neurosis; and second, there are as many views on its relation to delinquency and crime as there are psychiatrists.

A psychiatrist who is an outstanding expert on neurosis recently made the following observation: $:^{188}$

Probably nothing has been less conclusively defined than the nature of the neurotic process; and about nothing is there more confusion between laymen and behavioral scientists, among the several varieties of behavioral scientists, and even within the close fraternity of psychiatrists and the even closer fraternity of analysts.

This has been echoed by numerous experts. But it is not only the "nature of the neurotic process" that is in doubt. Usually, many more aspects of the concept are brought into question, as can be seen from the following typical conclusion: "Psychiatric diagnosis of neurosis is not yet standardized; there is variation in the nomenclature and the meaning ascribed to the diagnostic categories. There is widely differing emphasis on phenomenology, and etiology."188

Despite this reported state of uncertainty and the apparent divergence in viewpoints, neurosis is usually denominated a "disease." One psychiatrist, for example, counsels that neurosis "is always to be looked upon as a sickness (disease). . .".190 Another has pointed out that "mental disease is a term which includes psychosis and neurosis."191 No psychiatrist who takes the position that neurosis is a disease, however, has ever specified the organ in which it occurs, the type of lesion involved, or the kind of trauma, chemical imbalance, bacteria, virus, or other agent thought to be instrumental in its causation. If neurosis is a disease and if psychiatrists proceed in the manner of other medical practitioners-a point on which they unblushingly

${ }^{187}$ Glover, Outline of the Investigation and Treatment of Delinquency in Great Britain: 1912-1948: With Special Reference to Psychoanalytical and Other Psychological Methods, in EIsster, op. cit. supra note 26 , at 435 .

${ }^{188}$ Kubic, Social Forces and the Nezrotic Process, in Arexander H. Leiciron, JoHn A. CLAUsen \& Robert N. Wirson (Eds.), Explorations in Soctal Psychitry 8o (1957).

${ }^{189}$ Freedman \& Hollingshead, Neurosis and Social Class, I13 AM. J. Psychistry 769, 771 (1957).

${ }^{100}$ Ginsburg, supra note 100, at 58.

191 Wertham, Psychoauthoritarianism and the Law, 22 U. CHI. L. Rev. 336, 337 (x955). 
insist-then it is incumbent upon them to show diseased tissue in neurosis. On the other hand, there are some psychiatrists who say that neurosis is not a disease. Some say that neurosis is the inability to get along with people. ${ }^{192}$ But that is not disease; nor is it a medical problem. Another view has it that neurosis, and psychosis, too, for that matter, are not diseases located in the individual, but are problems involving group organization. ${ }^{193}$ But this is a concern of sociology, not medicine.

If neurosis is a disease, then it, like psychopathic personality, is one of the strangest kind of disease imaginable. This is certainly the impression one gets from a very recently-issued report of a comprehensive and elaborate research on the relationship between mental illness and social class, undertaken by a team of psychitrists, sociologists, psychologists, and others. Based on their study of the processes out of which psychiatric diagnoses emerge, these investigators were forced to the following observation: $:^{194}$

We take the position that a neurosis is a state of mind not only of the sufferer, but also of the therapist, and it appears likewise to be connected to the class positions of the therapist and the patient. A diagnosis arises from a number of conditioning factors: the experiences of the patient, the training and techniques of the doctor, as well as the social values of the community. Stated otherwise, a diagnosis of neurosis is a resultant of a social interactional process which involves the patient, the doctor, and the patient's position in the status structure of the community.

Apparently, then, the diagnosis of neurosis in a "patient" is dependent on the intricate convergence of a number of factors - the mental condition of the psychiatrist, a process of social interaction, the relative social class positions of the psychiatrist and the patient, and the social values prevailing in the community. These researchers also learned that the concept of neurosis can have reference to either a theological dogma, a philosophical premise, or a bodily disturbance: "The sinfulness of the Bible, the Angst of the Kierkegaardians, the 'nausea' of the existentialists, and the 'stress' of the internists are all syndromes which, may be and have been subsumed under the term neurosis by some experts."195 It is clear that one cannot be too sure whether an attack of neurosis is a problem calling for the ministrations of the physician or of the preacher.

It should be reiterated that the problems associated with the diagnosis of neurosis, as is true of other psychiatric diagnoses and concepts, are not matters of mere academic import. The psychiatrist's views on neurosis and all the inferences he draws from them can affect offenders in a multitude of ways. It is obviours that if a psychiatrist considers psychopathic personality to be a mental disease but does not so consider neurosis, or vice versa, and if a criminal act resulting from a mẹntal

${ }^{109}$ Redlich, The Concept of Health in Pyschiatry, in Leighron; Clausen, and WiLson, op. cit. stipra note 188 , at $\mathrm{r} 44$.

${ }^{103}$ Ruesch, Social Factors in Therapy: $A$-Brief, Review, in-Ass'N-For REsearch IN NERvous AND MENtal Disease, Psychiatric Treatmient 71 ( 1953 ).

104 August B. Hollingshead \& Fredrick C. Redlich, Social Class and Mental Ilolness-237 (1958).

${ }^{200} \mathrm{Id}$. at 239. 
disease is not punishable, the differential diagnosis of these two conditions becomes a critical matter. Therefore, it is important to take a look at the notions of the psychiatrists on the relationship between neurosis and criminal or delinquent behavior, which, as has been stated and as can be guessed by now, are the subject of abounding controversies.

One psychiatrist includes "the child's delinquent behavior-all delinquent behavior-within the framework of the neuroses." He contends that "the delinquent act is but a special type-a syndrome ... within the group designated the neuroses." "198 Yet, one psychiatrist found that only twenty-four, or 6 of one per cent, out of 4,000 delinquents examined by him gave evidence of a psychoneurotic reaction. ${ }^{197}$ On the other hand, in the well-known study by the Gluecks, it was -found that 24.6 per cent of 500 delinquents were neurotic-a proportion over forty times larger than that found in the report just cited. ${ }^{108}$ It is the observation of a psychiatrist that "most" children with a long history of delinquency referred to child guidance clinics are neurotic. ${ }^{199}$ Yet, psychiatrists who examined the more serious delinquents referred to them by a juvenile court during a one-year period diagnosed only 4.4 per cent as neurotic. ${ }^{200}$ One psychiatrist has expressed the opinion that psychoneurosis "constitutes quite a considerable group of the delinquents." ${ }^{201}$ This is contradicted by another, however, who says that it is "rare" for neurosis to be a decisive factor in delinquency. ${ }^{202}$

Into the midst of these ongoing debates and these diligent efforts to settle on the incidence of neurosis among delinquents, one psychiatrist recently interjected what is not a new, but is, nonetheless, a most disconcerting, observation, and one which will be discussed presently. He announced that there is an antithetical relation between psychoneurosis and delinquency! $-{ }^{203}$ thereby embarrassing all those practitioners who have given sworn testimony before any number of boards, committees, and commissions that neurosis is a cause of delinquency and who, through the years, have been confidently making known publicly the varying proportions of delinquents in whom they have found neurosis. The issue is further complicated by those psychiatrists who find delinquents to be less neurotic, or less often neurotic, than nondelinquents. Jenkins, as do others, comes to this conclusion. He first dismisses the theory that neurosis can account for all or a major fraction of delinquency as one that "neither rings true nor makes sense." He then reasons that the delin-

${ }^{100}$ Gardner, The Community and the Aggressive Child: The Expression of the Aggressive-Destructive Impulses in Juvenile-Delinquent Acts, 33 MeNTal HyGiene 537, 541 (1949).

${ }_{107}$ East, cited by Gillespie, Psychoneturosis and Criminal Behaviour, in Radzinowicz \& Turner, op. cit. supra note 42 , at 72 .

${ }^{298}$ Sheidon \& Eleanor T. Glueck, Unzaveling Juvenile Delinquency 239.40 (1950).

${ }^{109}$ Lippman, Difficulties Encountered in the Psychiatric Treatment of Chronic Juvenile Delinquents, in Eisster, op. cit. supra note 26, at $15 \%$.

${ }^{200}$ Juvenile Court of Cuyahoga County (Cleveland) Ans. Rep. table 15, at 38 (1957).

${ }^{201}$ Rees, Mental Variations and Criminal Behaviour, in RADzinOwicz \& TURNer, op. cit. stupra note 42 , at 6 .

${ }^{202}$ Chess, Invenile Delinquency: Whose Problent?, Fed. Prob., June 1955, pp. 29, 30.

${ }^{208}$ Glover, Psycho-Analysis and Criminology: A Political Survey, 37 INT'L J. Psxcro-Anal. 311,314 (I956). 
quent is inclined to be less neurotic than the nondelinquent. And he pushes the point even further by describing the delinquent as one who is less prone to manifest neurotic tendencies than are people in general. ${ }^{204}$ In the research by the Gluecks, in which a comparison is made between nondelinquents and delinquents, a significantly higher proportion of neurotics was found among the former than among the latter. ${ }^{205}$

But suppose, for purposes of argument, it is granted that a major fraction (or even all) offenders are neurotic. This would not distinguish them from various specified groups in the population, from a large majority of human beings, or even from all the inhabitants of this planet, if the judgment of certain psychiatrists can be trusted. Take, for example, the research on the relationship between mental illness and social class already referred to. One of its findings is that a considerable proportion of the neurotics found in the upper social classes comprised psychiatrists, psychologists, nurses, social workers, artists, other professional workers, and persons in the communication business. ${ }^{200}$ In another research, it was discovered that college students are as frequently neurotic as are prison inmates. ${ }^{207}$ In a survey of the incidence of mental disorders among a random sample of the residents of a community of three thousand people, it was found that fifty-seven per cent were neurotic. ${ }^{208}$ One psychiatrist has claimed, "To understand the neuroses is to understand the average person...."209 Another has insisted that few residents of this continent can be called "nonneurotic."110 Finally, a psychiatrist has gone on record as concurring with another expert whom he paraphrases as saying that "all persons, in all cultures, are victimswhether to a greater or to a lesser extent-of a widely prevalent social neurosis the existence of which is now evident beyond any question . . .,"211 thus still leaving unsettled the question whether neurosis is a social or a medical phenomenon.

When it comes to the matter of similarities and differences between neurosis and psychopathic personality, the chaos is complete. Sometimes, one encounters the view that these diseases are worlds apart, and sometimes, that they are one and the same. Thompson holds to the former view, saying that the dissimilarity between the two diseases is "essentially complete."212 In another source, he joins a colleague in the following elaboration: "The psychopath and psychoneurotic seem to be at opposite extremes with regard to personality function." 213 And they emphasize that when it comes to the traits characterizing the two diagnostic categories, "the in-

206 Jenkins, Adaptive and Maladaptive Delinquency, II Nervous CHILd 9, II (1955).

${ }^{208}$ Sheldon \& Eleanor T. Glueck, op. cit. supra note 198.

${ }_{200}$ Hollingshead \& Redlich, op. cit. supra note 194 , at 337.

${ }^{207}$ Levy et al., The Outstanding Personality Factors Among the Population of a State Penitentiary: A Preliminary Report, I3 J. Cins. \& EXPER. Psychopath. I17, I2I (1952).

${ }^{208}$ Leighton, The Distribution of Psychiatric Symptoms in a Small Town, 112 Axs. J. Psychitru 716,722 (1956).

${ }^{200}$ Leon J. Saul, Emotional Maturity vii (1947).

${ }^{210}$ James Clark Moloner, The Battle for Mental Health 8 (1952).

211 Thornton, Book Review, 4I J. Crm. L., C. \& P.S. 807 (195I).

212 ThOMPSON, op. cit. supra note I23, at 50 .

${ }^{210}$ Nielsen \& ThOMPson, op. cit. supra note 138 , at 185 . 
compatibility seems absolute."214 But this orientation is negated by Federn, who, in speaking of criminal psychopathy, holds that this condition is "usually combined with neurotic symptoms and neurotic character traits."215 And Schilder says he inclines to the view that the two terms, "psychopathic" and "neurotic," are "equivalent."216 Guttmacher goes even further toward obliterating the distinction when he writes that criminal psychopaths "suffer from a deep-seated neurosis."17

The opinions just recounted cast serious doubt, to say the least, on the separability of psychopathic personality and neurosis as two distinct and vastly dissimilar disease entities. Any lingering doubt is completely removed by still another theory that has numerous adherents among psychiatrists. This theory makes of psychopathic personality nothing more than a manifestation of neurosis. It is explained by those who identify with this school of thought that psychopathic personality is neurosis expressed in antisocial behavior. ${ }^{218}$ Persons are diagnosed as psychopathic, according to this scheme, "when their antisocial behavior is the principle [sic] manifestation of their neurosis." 219 But these definitions are precisely the ones psychiatrists give of neurotic delinquency itself, without reference in any manner or form to psychopathic personality. A typical example is the following: "The essential feature of neurotic delinquency is that it represents behavior directed against society to express a neurotic conflict." 220

Now, it so happens that such assertions-that psychopathic personality is neurosis manifested in antisocial behavior, that neurotic delinquency is the solution of neurotic conflicts through the commission of aggressive acts, and the simple assertion that neurotics do commit delinquency and crime-are in complete conflict with another postulate, referred to earlier in passing, often made by psychiatrists. This postulate affirms that it is inherent in the very nature of neurosis that those afflicted with it do not commit offenses. Further, it is contended that the psychopath "acts out" (to use the psychiatric jargon for the commission of aggressive, criminal, or destructive deeds), in contradistinction to the neurotic who does not act out, but rather suffers inwardly or escapes into fantasy. According to Alexander, for example, the very criterion that distinguishes psychopaths from neurotics is that "they [psychopaths] 'act out' their neurotic impulses, in contrast to psychoneurotics whose most important activity is in their fantasy."221 Sometimes the same point is made in a different way. Abrahamsen, to choose only one example from among many, claims that the offender may get relief from his conflicts through his antisocial actions, but that such an escape

214 Id. at 188 .

915 Paul Federi, Ego Psychology and the Psychoses i8o (Edoardo Weiss èd. I952).

210 SchldER, op. cit. supra note 48 , at 278 .

${ }^{217}$ Guttmacher, Medical Aspects of the Causes and Prevention of Crime and the Treatment of offenders, 2 BuLL. WHO 281 (1949).

218 Beulah Chamberlain Bosselaran, Neurosis and Psychosis 55 (2d ed. 1956).

210 Edward A. Strecker and others, Practical Clinical, Psychiatry 3 io (7th ed. 1951 ).

${ }^{220}$ Hyman S. Lippman, Treatment of the Child in.Emotional Conflict 19! (1956).

221 Franz Alexander, Fundamentals of. Pychoanalysts 235 (I948). 
is not open to a neurotic because he is "too inhibited." However, Banay declares that just the opposite is true-namely, that one of the means by which offenders get release from neurotic conflicts is to commit delinquencies rather than to remain inhibited. ${ }^{223}$ And others go even further and say that a neurotic offender commits crimes "precisely because he is over-inhibited. . .."224

Understandably, two psychiatrists recently sought to evade this whole horrendous muddle. Brancale and Heyn reported that those offenders whom they now diagnose as neurotic correspond to those formerly diagnosed as psychopathic. ${ }^{225}$ And Karpman, who is Chief Psychotherapist at St. Elizabeth's Hospital, apparently refusing to let this diagnostic fuss stay his therapeutic hand, has solved the problem at least for one category of offenders: "I have developed a rather simple method of dealing with sexual offenders; I merely change the diagnosis from one of psychopathy to one of neurosis and then proceed to treat as any neurosis. ${ }^{226}$

The diagnosis of neurosis obviously is no more reliable or valid than is the diagnosis of psychopathic personality. This and the other criticisms that can be made of the diagnosis of neurosis need not be rehearsed in detail. They are precisely the same as have already been made respecting psychopathic personality.

\section{VI}

ConCLUSIONS

Psychiatric testimony should not be admissible in court. The courts have traditionally followed the principle that expert testimony and evidence that purport to be scientific will not be admissible unless their reliability and validity have been amply tested and unless substantial agreement among the appropriate experts has been demonstrated. When it comes to psychiatric testimony, the courts are acting in heedless disregard and flagrant violation of this eminently sound principle. It should be unmistakably clear on the basis of the evidence adduced here-only a tiny part of the available evidence-that psychiatrists have not attained the level of competence and scientific reliability and validity necessary to make their testimony eligible for serious consideration by the courts. Neither should it be looked upon as an objective and sound basis for coercive decisions, judicial or correctional. The courts should not allow psychiatric testimony to be heard, irrespective of whether the psychiatrists are partisan or court-appointed, attached to a court clinic or to a hospital.

Furthermore, the courts and correctional agencies should not persist in giving legal and official support and sanction to the almost universal fallacy of considering psychiatrists to be experts on human behavior, motivation, personality, interpersonal

${ }^{223}$ Abrahamsen, Family Tension, Basic Cause of Criminal Behavior, 40 J. CrIM. L. \& Crimnology 330,336 (1949).

${ }^{38}$ Ralph S. BANAy, Youth in Despatr I4I (r948).

224 Albert Ellis \& Ralph Brancale, The Psychology of Sex Ofpenders 39 (1956). [Italics in original.]

${ }_{295}$ Brancale \& Heyn, Detection, Classification, and Treatment of the Youthful Offender, Fed. Prob., March 1957, pp. 33, 36 .

${ }^{220}$ Benjamin Karpman, The Sexual Offender and His Offenses 574 (1954). 
relations, problems of social organization, emotional reactions, crime and delinquency, other social problems, and similar nonmedical topics. It is astounding that judges and correctional officials continue to view psychiatrists as experts on human behavior when there is considerable experimental and other research which shows laymen to be superior to psychiatrists and associated personnel in the judgment of peoples' motives, emotions, abilities, personality traits, and action tendencies. ${ }^{227}$

It is certainly puzzling that the courts insist on admitting psychiatric testimony in spite of the fact that some psychiatrists have repeatedly given candid and pointed warnings against the dogmatism, aggressiveness, dubious tactics, and irresponsibility of some of their colleagues, particularly those who have succeeded in overselling psychiatry to the legal profession and to the general public. Some of the more cautious practitioners know full well that psychiatry does not have knowledge that would be helpful in the administration of justice. One of these, whose statement to this effect has already been cited, ${ }^{228}$ makes the following rejoinder to the claim of some psychiatrists that their success in bringing about changes in the laws of criminal responsibility is due to the increasing knowledge of human behavior accumulated during the past fifty years: "But is this why they have succeeded? I think not. They have succeeded rather because they now possess more social power than they had in the past." 229

${ }^{227}$ Taft, The Ability to Judge People, 52 Psychologrcal Bur.. I (1955).
${ }^{228}$ See supra note 15.

${ }^{230}$ Szasz, supra note 15 , at 314 . 